\title{
INHIBIN IMMUNOREACTIVITY IN GONADAL AND NON-GONADAL TUMORS
}

\author{
F. H. De Jong, ${ }^{1.2}$ A. J. Grootenhuis, ${ }^{1}$ J. Steendergen, ${ }^{1}$ F. J. van Sluis,,${ }^{4}$ J. A. Foekens, ${ }^{5}$ \\ F. J. W. Ten Kate, ${ }^{3}$ J. W. Oosterhuis, ${ }^{6}$ S. W. J. Lamberts ${ }^{2}$ and J. G. M. KLIJN ${ }^{5}$ \\ Departments of 'Biochemistry (Division of Chemical Endocrinology), ${ }^{2}$ Internal Medicine and ${ }^{3}$ Pathology, \\ Erasmus University Rotterdam, ${ }^{4}$ Department of Clinical Sciences of Companion Animals, State Univer- \\ sity Utrecht, 'S Division of Endocrine Oncology, Dr Daniel den Hoed Cancer Center, Rotterdam and \\ ${ }^{6}$ Department of Pathology, State University Groningen, The Netherlands
}

\begin{abstract}
Summary-Inhibin immunoreactivity was estimated in a number of gonadal and non-gonadal tumors. Dog Sertoli cell tumors and human granulosa cell and Leydig cell tumors contained high concentrations of inhibin-like material. Levels, comparable with those in normal testes and ovaries were detected in human testicular non-seminomas and in ovarian cystadenomas, thecomas and adenofibromas. No activity was found in human testicular Sertoli/Leydig cell tumors and seminomas and in ovarian adenocarcinomas, teratomas and a dysgerminoma. Furthermore, human adrenal cortical tissue (tumor and hyperplastic adrenal) contained inhibin immunoreactivity. No activity was found in human tumors of the stomach, gut, liver, kidney, pancreas and mammary gland or in meningiomas. It is concluded that inhibin is not a good marker for specific gonadal tumors. Inhibin might have intratumor actions as a growth or differentiation factor.
\end{abstract}

\section{INTRODUCTION}

Inhibin has been defined as a gonadal glycoprotein hormone, which can suppress the pituitary production and secretion of gonadotropins, preferentially that of FSH [1]. Inhibin consists of two disulphide-linked subunits: the $\alpha$-subunit is combined with either of two $\beta$-subunits, $\beta-\mathrm{A}$ or $\beta-\mathrm{B}$. The primary structure of the inhibin subunits shows homology with that of a number of growth and differentiation factors, e.g. Müllerian inhibiting substance and transforming growth factor- $\beta$ (see for reviews, De Jong [2], Ying [3], de Kretser and Robertson [4]). Combination of two inhibin $\beta$-subunits leads to the formation of activin, a protein which counteracts the action of inhibin on the pituitary secretion of FSH $[5,6]$.

The mRNA for the inhibin subunits is expressed in a large number of tissues apart from the gonads [7], and even in the gonads themselves inhibin subunits have been detected outside the cells which were traditionally believed to be the source of inhibin viz. the Sertoli cells in the testis [8] and the granulosa cells in the ovary [9]: Lee et al. [10] and Risbridger et al. [11] showed inhibin production in Leydig cells,

Proceedings of the 2nd International EORTC Symposium on "Hormonal Manipulation of Cancer: Peptides, Growth Factors and New (Anti-)Steroidal Agents", Rotterdam, The Netherlands, 9-11 April 1990. whereas a number of other authors showed the presence of inhibin subunits in theca or corpus luteum cells in the ovary (see for review, de Jong et al. [12]).

Recently, the presence of high peripheral levels of inhibin immunoreactivity in women with granulosa cell tumors was described [13]. In the present study, levels of inhibin immunoreactivity in human ovarian and testicular tumor tissue were estimated in order to ascertain the specificity of inhibin as a marker for granulosa and Sertoli cell tumors. Because of the fact that the incidence of Sertoli cell tumors in men is extremely low, this type of tumor was obtained from dogs. Finally, in order to substantiate the specificity of inhibin as a gonadal tumor marker, inhibin immunoreactivity was also estimated in a number of tumors of other organs.

\section{MATERIALS AND METHODS}

\section{Tumor tissues}

Sertoli cell tumors were obtained from dogs, whereas all other tumor material was of human origin. All tumor tissues were placed on ice immediately after excision. Part of the tissue was used for routine pathological procedures; the remaining tissue was stored at $-80^{\circ} \mathrm{C}$ until processing. The frozen tissue was pulverized and homogenized as described earlier [14]. The 
homogenates were centrifuged for $30 \mathrm{~min}$ at $50,000 \mathrm{~g}$ at $4^{\circ} \mathrm{C}$, and the supernatant was used for the estimation of inhibin (see below) and protein [15].

\section{Inhibin assays}

Inhibin immunoreactivity was assayed using the antiserum against bovine inhibin (No. 1989) described by Robertson et al. [16], using radioiodinated $32 \mathrm{kDa}$ bovine inhibin as a label. The antiserum and the material for iodination were purchased from the Department of Anatomy, Monash University, Melbourne, Australia. Inhibin was labeled using $\left[{ }^{125} \Gamma\right]$ sodium iodide (Amersham, Amersham, U.K.) and Protag (Baker, Deventer, The Netherlands) as the oxidizing agent. Labeled protein was isolated after chromatography on prepacked Sephadex G-25 columns (PD-10, Pharmacia, Uppsala, Sweden). The standard used in the immunoassay was a bovine ovarian follicular fluid preparation with the arbitrary potency of $1 \mathrm{U} / \mu \mathrm{g}$ protein. The International Research Standard for inhibin $(86 / 890,[17])$, has a specific activity of $60 \pm 10 \mathrm{U} / \mu \mathrm{g}$, when expressed in units of this bovine follicular fluid standard.

Inhibin bioactivity was estimated as described by Grootenhuis et al. [18], using the same standard.

\section{RESULTS}

\section{Testicular tumors}

Dog Sertoli cell tumors. Inhibin bioactivity levels in the Sertoli cell tumors and in canine control testes are shown in Fig. 1, together with the results of the immunological esti- mations of inhibin in plasma from these animals. Testicular inhibin bioactivity in the tumor tissue was significantly higher than that in the control testes $(P<0.05)$. Similarly, the peripheral levels of immunoreactive inhibin were significantly higher when compared with those in control dogs $(P<0.01$ after logarithmic transformation). There was no relationship between testicular and peripheral concentrations of inhibin.

Human testis tumors. Results of estimations of immunoreactive inhibin in homogenates of human testicular tumors are summarized in Fig. 2. High concentrations were found in two out of three Leydig cell tumors, whereas nonseminomas contained inhibin levels comparable to those in normal human testes. In contrast, very low concentrations or non-detectable levels were found in mixed Sertoli cell-Leydig cell tumors and in seminomas.

\section{Ovarian tumors}

Levels of immunoreactive inhibin in human ovarian tumors are shown in Fig. 3. Significant concentrations were found in control ovaries, cystadenomas, thecomas and adenofibromas, whereas much higher levels were present in the supernatant of the granulosa cell tumor homogenates. The concentrations of inhibin immunoreactivity in adenocarcinomas, teratomas and a dysgerminoma were below the level of detection of the assay.

\section{Other tumors}

Finally, inhibin immunoreactivity was estimated in supernatants of homogenates of a

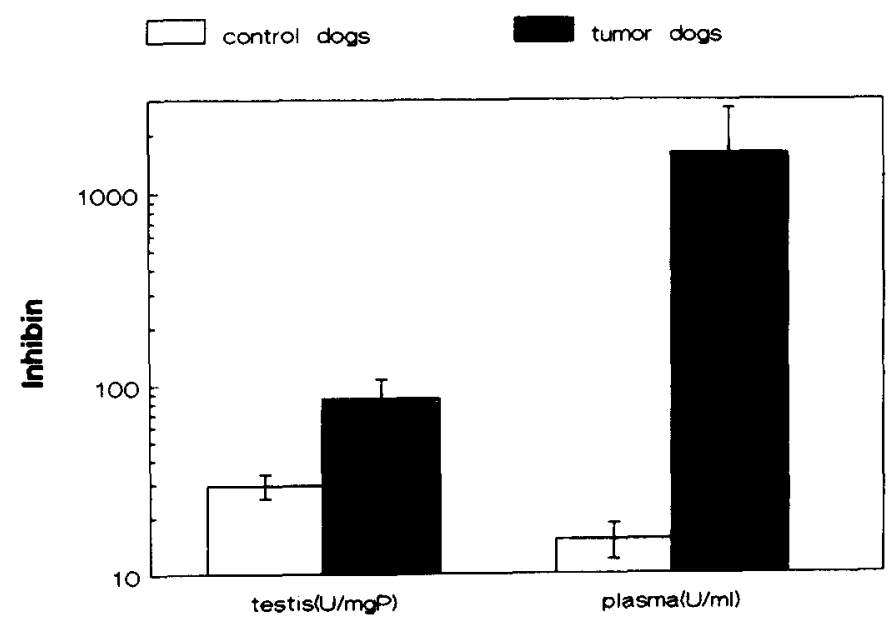

Fig. 1. Bioactive inhibin in control testes (open bar) or Sertoli cell tumors (hatched bar) from dogs and immunoreactive inhibin in plasma from the same animals (means $\pm \operatorname{SEM}, n=5$ ). Data from Grootenhuis et al. [20]. 


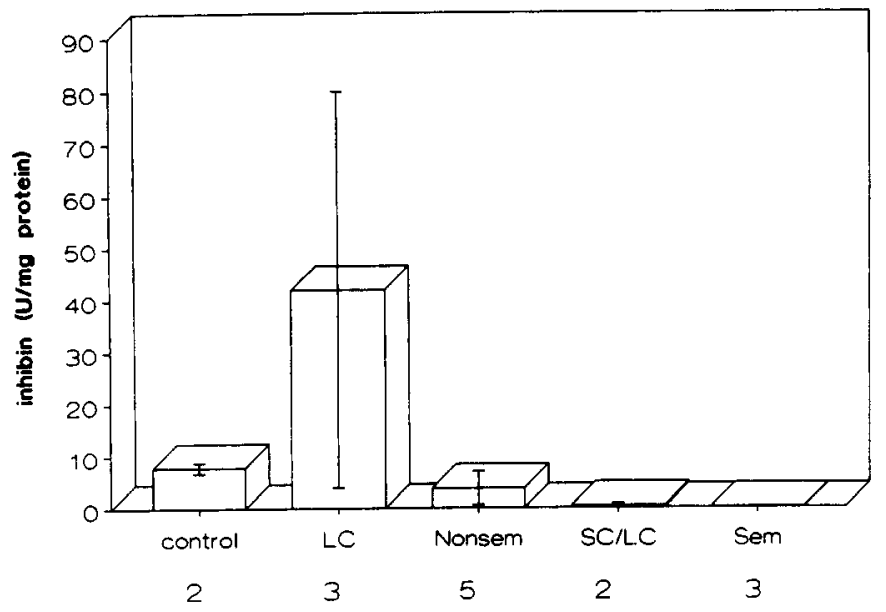

Fig. 2. Inhibin levels in human control testes and in testicular neoplasms: Leydig cell tumors (LC), nonseminomas (Nonsem), Sertoli cell/Leydig cell tumors (SC/LC) and seminomas (Sem). Figures indicate numbers of samples investigated.

number of other tumors. Inhibin was only detected in adrenal cortical tissue (hyperplastic adrenal: $3 \mathrm{U} / \mathrm{mg}$ protein; adrenal tumor: $1 \mathrm{U} / \mathrm{mg}$ protein), whereas no immunoreactivity was found in tumors of the stomach $(n=3)$, gut $(n=4)$, liver $(n=3)$, kidney $(n=3)$, pancreas $(n=2)$ and mammary gland $(n=5)$ or in meningiomas $(n=5)$.

\section{DISCUSSION}

Bioactive inhibin is produced in the granulosa cells of the ovary [9] and the Sertoli cells of the testis [8]. Furthermore, inhibin bio- and immunoactivity has been reported to be present in culture medium of Leydig cells $[10,11]$ and the presence of inhibin subunits has been reported in a number of other tissues including the adrenal gland, the kidney and the brain (see [12]).
The results reported here indicate the presence of inhibin immunoreactivity in Sertoli and granulosa cell tumors. It is not clear if this immunoreactivity should be ascribed to dimers of the inhibin $\alpha$ - and $\beta$-subunits or to the presence of an $\alpha$-subunit, combined with part of its pro-sequence, which was shown to crossreact in the immunoassay used here [19]. Also, high circulating levels of immunoreactive inhibin were found in dogs with Sertoli cell tumors [20] and in women with granulosa cell tumors [13]. However, other types of tumors in the testis and the ovary also appear to contain inhibin immunoreactive material; in patients with these types of tumor increased peripheral levels of inhibin might also occur, thus rendering the specificity of inhibin as a marker for granulosa and Sertoli cell tumors questionable. Most of the non-gonadal tumours, however, did

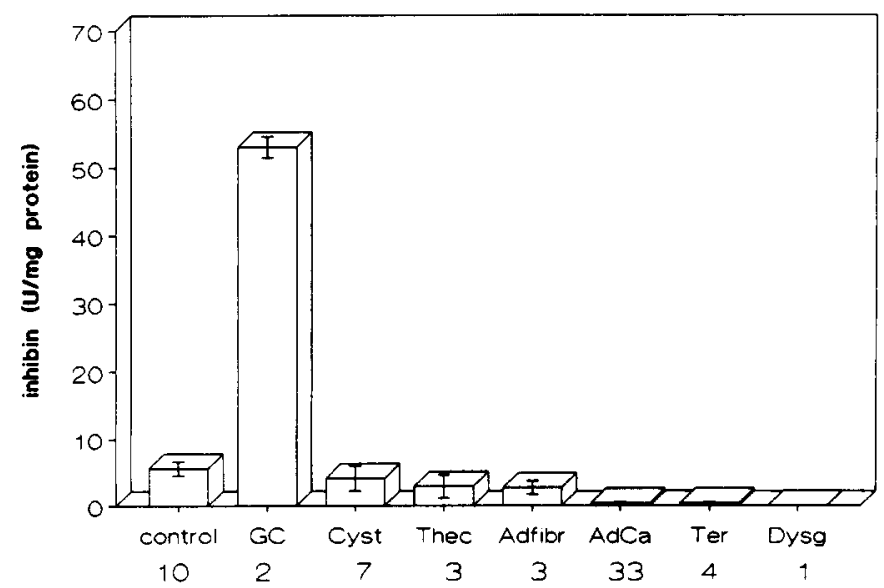

Fig. 3. Inhibin levels in human control ovaries and in ovarian neoplasms: granulosa cell tumors (GC), cystadenomas (Cyst), thecomas (Thec), adenofibromas (Adfibr), adenocarcinomas (AdCa), teratomas (Ter) and a dysgerminoma (Dysg). Figures indicate numbers of samples investigated. 
not contain detectable amounts of inhibin immunoreactivity.

The presence of inhibin immunoreactivity in testicular non-seminomas is interesting, since this tumor may consist of a number of primitive cell types; so far, no clear correlation with a subtype of non-seminomas was observed. The finding that mixed Leydig-Sertoli cell tumors did not contain inhibin immunoreactivity is not understood, since both cell types contributing to this tumor apparently contain high concentrations of the immunoreactivity. Finally, the presence of high concentrations of inhibin-like material in tumor tissues and the large number of intra- and extra-gonadal effects of inhibin and related substances (see [12]), suggest that inhibin may affect cellular functions in the tumor, or in other cell types, such as erythropoietic cells [21] or thymocytes [22]. These possible effects of inhibin and related proteins as growth and differentiation factors should be envisaged when dealing with patients with inhibin-producing tumors.

\section{REFERENCES}

1. Burger $H$. and Igarashi M.: Inhibin: definition and nomenclature, including related substances. Endocrinology 122 (1988) 1701-1702.

2. De Jong F. H.: Inhibin. Physiol. Rev. 68 (1988) 555-607.

3. Ying S. Y.: Inhibins, activins, and follistatins: gonadal proteins modulating the secretion of follicle-stimulating hormone. Endocr. Rev. 9 (1988) 267-293.

4. de Kretser D. M. and Robertson D. M.: The isolation and physiology of inhibin and related proteins. Biol. Reprod. 40 (1989) 33-47.

5. Ling N., Ying S. Y., Ueno N., Shimasaki S., Esch F., Hotta $M$. and Guillemin R.: Pituitary FSH is released by a heterodimer of the $\beta$-subunits from the two forms of inhibin. Nature (Lond.) 321 (1986) 779-782.

6. Vale W., Rivier J., Vaughan J., McClintock R., Corrigan A., Woo W., Karr D. and Spiess J.: Purification and characterization of an FSH releasing protein from porcine ovarian follicular fluid. Narure (Lond.) 321 (1986) 776-779.

7. Meunier H., Rivier C., Evans R. M. and Vale W.: Gonadal and extragonadal expression of inhibin $\alpha, \beta \mathrm{A}$ and $\beta \mathrm{B}$ subunits in various tissues predicts diverse functions. Proc. Natl. Acad. Sci. U.S.A. 85 (1988) 247251.

8. Steinberger A. and Steinberger E.: Secretion of an FSH-inhibiting factor by cultured Sertoli cells. Endocrinolog! 99 (1976) 918-921.

9. Erickson G. F. and Hsueh A. J. W.: Secretion of "inhibin" by rat granulosa cells in vitro. Endocrinology" 103 (1978) 1960-1963.
10. Lee W., Mason A. J., Schwall R., Szonyi E. and Mather J. P.: Secretion of activin by interstitial cells in the testis. Science (N.Y.) 243 (1989) 396-398.

11. Risbridger G. P., Clements J., Robertson D. M., Drummond A. E., Muir J., Burger H. G. and de Kretser D. M.: Immuno- and bioactive inhibin and inhibin $\alpha$-subunit expression in rat Leydig cell cultures. Mol. Cell. Endocrinol. 66 (1989) 119-122.

12. de Jong F. H., Grootenhuis A. J., Klaij I. A. and van Beurden W. M. O.: Inhibin and related proteins: localization, regulation and effects. In Circulating Regulatory Factors and Neuroendocrine Functions (Edited by J. Porter). Plenum Press, New York (1990) pp. 271-294.

13. Lappöhn R. E., Burger H. G., Bouma J., Bangah M., Krans $\mathbf{M}$. and de Bruijn H. W. A.: Inhibin as a marker for granulosa-cell tumors. New Engl. J. Med. 321 (1989) 790-793.

14. EORTC Breast Cancer Cooperative Group. Revision of the standards for the assessment of hormone receptors in human breast cancer. Eur. J. Cancer Clin. Oncol. 16 (1980) 1513-1515

15. Bradford M. M.: A rapid and sensitive method for the quantitation of microgram quantities of protein utilizing the principle of protein-dye binding. Anal. Biochem. 72 (1976) 248-254.

16. Robertson D. M., Hayward S., Irby D., Jacobson J., Clarke L., McLachlan R. I. and de Kretser D. M.: Radioimmunoassay of rat serum inhibin: changes after PMSG stimulation and gonadectomy. Mol. Cell. Endocrinol. 58 (1988) 1-8.

17. Waites G. M. H., Bialy G., Gordon W. L., Findlay J. K., de Jong F. H., Robertson D. M., Schwartz M. B. and Storing P. L.: International research standard for inhibin. In Inhibin-Non-steroidal Regulation of Follicle Stimulating Hormone Secretion (Edited by H. G. Burger, J. K. Findlay, D. M. de Kretser and M. Igarashi). Raven Press, New York (1987) pp. 281-287.

18. Grootenhuis A. J., Steenbergen J., Timmerman M. A., Dorsman A. N. R. D., Schaaper W. M. M., Meloen R. H. and de Jong F. H.: Inhibin and activinlike activity in fluids from male and female gonads: different molecular weight forms and bioactivity/ immunoactivity ratios. J. Endocrinol. 122 (1989) 293-301.

19. Robertson D. M., Giacometti M., Foulds L. M., Lahnstein J., Goss N. H., Hearn M. T. W. and de Kretser D. M.: Isolation of inhibin $\alpha$-subunit precursor proteins from bovine follicular fluid. Endocrinology 125 (1990) $2141-2149$

20. Grootenhuis A. J., van Sluijs F. J., Klaij I. A., Steenbergen J., Timmerman M. A., Bevers M. M., Dieleman S. J. and de Jong F. H.: Inhibin, gonadotrophins and sex steroids in dogs with Sertoli cell tumors. J. Endocrinol. 127 (1990) 235-242

21. Yu J., Shao L., Lemas V., Yu A. L., Vaughan J., Rivier $J$. and Vale $W$ : Importance of FSH-releasing protein and inhibin in erythrodifferentiation. Nature (Lond.) 330 (1987) 765-767

22. Hedger M. P., Drummond A. E., Robertson D. M., Risbridger G. P. and de Kretser D. M.: Inhibin and activin regulate $\left[{ }^{3} \mathrm{H}\right]$ thymidine uptake by rat thymocytes and 3 T 3 cells in vitro. Mol. Cell. Endocrinol. 61 (1989) 133138 